ISSN No.2088.2017

Vol. I Nomor 1, Agustus 2012, hlm. 1-80

JURNAL ILMIAH MUTIARA MUHAMMADIYAH

Penerbit

Lembaga Penelitian Dan Pengembangan Universitas Muhammadiyah Luwuk 


\section{JURNAL ILMIAH MUTIARA MUHAMMADIYAH \\ ISSN No. 2088-2017 \\ Volume I, Nomor 1, Agustus 2012, hlm. 1-80}

\section{DAFTAR ISI}

1. Pelaksanaan Perjanjian Bagi Hasil Tanah Pertanian Di Kecamatan Simpang Raya Kabupaten Banggai. Risno Mina.....

2. Pelaksanaan Fungsi Dan Wewenang Badan Permusyawaratan Desa Dalam Kerangka Otonomi Desa Di Kecamatan Luwuk Kabupaten Banggai.

Nirwan M. Nur....

3. Efektivitas Pelaksanaan Program Nasional Pemberdayaan Masyarakat (PNPM) Mandiri Perdesaan Terhadap Kesejahteraan Sosial Masyarakat Desa Lobuton Kabupaten Banggai Kepulauan. Kisman Karinda.....

4. Mutu Fisik Dan Organoleptik Sayur Lilin (Terubuk) Pada Beberapa Teknik Pengemasan Sebagai Upaya Meningkatkan Pendapatan Petani. Ramadhani Chaniago dan Winarto Ramlan

5. Tingkat Kualitas Nelayan Di Tanjung Kelurahan Karaton Kecamatan Luwuk Kabupaten Banggai. Mukhtar Lutfie.

6. Pengaruh Pendidikan Formal Dan Non Formal Terhadap Peningkatan Ekonomi Masyarakat Pembuat Batu Bata Di Desa Unjulan

Kecamatan Luwuk. Irwan Moridu

7. Intensitas Penggunaan Tanaman Obat Keluarga (Toga) Pada Ibu Rumah Tangga Dan Faktor Yang Mempengaruhinya. Nurhidaya Layoo.

8. Kajian Permasalahan Pengembangan Budidaya Ikan Kerapu Dalam Keramba Jaring Apung Di Kabupaten Situbondo. Sri Sukari Agustina 


\title{
KEPEMIMPINAN DALAM BUDAYA ORGANISASI
}

\author{
Oleh : \\ Mohammad Gifari Sono
}

\begin{abstract}
ABSTRAK
Budaya organisasi tidak dapat dipisahkan dengan kepemimpinan dalam organisasi karena budaya organisasi tumbuh dan berkembang bersama pendiri dan pemimpin organisasi yang kuat. Perkembangan organisasi sangat tergantung pada kemampuan pemimpinnya. Secara tradisional pendiri dan pemimpin organisasi memiliki pengaruh yang besar terhadap budaya awal organisasi. Mereka memiliki visi tentang akan menjadi apa organisasi itu nantinya. Apabila organisasi dapat mencapai kesuksesan, maka visi pendiri tersebut selanjutnya dianggap sebagai faktor penentu utama keberhasilan organisasi. Pada titik ini seluruh kepribadian para pendiri dan pemimpin jadi melekat dalam budaya organisasi.
\end{abstract}

Kata kunci : budaya, organisasi, kepemimpinan

\section{PENDAHULUAN}

Budaya organisasi merupakan kebiasaan, tradisi, dan tata cara umum dalam melakukan sesuatu dan sebagian besar berasal dari pendiri organisasi (Falikhatun, 2003). Ukuran kecil organisasi yang merupakan ciri ketika organisasi baru pertama kali berdiri, lebih memudahkan pendiri untuk memaksakan visi mereka kepada seluruh anggota organisasi. Proses penciptaan budaya organisasi terjadi melalui 3 cara, (Sunyoto \& Burhanudin, 2011) yaitu :

1. Pendiri hanya merekrut dan mempertahankan karyawan yang memiliki satu pikiran dan satu perasaan dengan mereka.

2. Mereka melakukan indoktrinasi dan mensosialisasikan cara pikir serta berperilaku mereka kepada karyawan.

3. Perilaku pendiri sendiri bertindak sebagai model peran yang mendorong karyawan untuk mengidentifikasi diri dan menginternalisasi keyakinan, nilai, serta asumsi tersebut.

Menurut Jusi 2001 (dalam Moeljono, 2005), budaya yang kuat didukung oleh faktor-faktor : leadership, sense of direction, climate, positive teamwork, value add systems, enabling structure, appropriate competences, and developed individual. Di antara faktor pendukung tersebut, menurut pengalaman ternyata faktor leadership sangat menonjol, dalam arti bahwa komitmen, kesungguhan tekad dari pimpinan terutama pimpinan puncak suatu organisasi, merupakan faktor utama dan sangat mendukung terlaksananya suatu budaya di perusahaan.

Budaya organisasi yang efektif membantu organisasi mengantisipasi dan beradaptasi dengan perubahan Iingkungan. Proses pengembangan budaya organisasi yang adaptif dimulai dengan kepemimpinan. Seorang pemimpin harus dapat 
menciptakan dan mengimplementasikan visi dan strategi yang sesuai dengan konteks organisasi. Kemampuan adaptasi harus ditingkatkan dari waktu ke waktu dengan mengkombinasikan antara sukses organisasi dan fokus kepemimpinan yang spesifik.

\section{a. Pengertian Kepemimpinan}

Banyak konsep tentang definisi kepemimpinan dari ahli administrasi dan manajemen. menurut Joseph C. Rose yang berpendapat bahwa kepemimpinan adalah sebuah hubungan yang saling mempengaruhi di antara pemimpin dan pengikut (bawahan) yang menginginkan pembahan nyata yang mencerminkan tujuan bersamanya.

Ralph M. Stogdill (dalam Sopiah, 2008) mendefinisikan kepemimpinan manajerial sebagai proses mengarahkan dan mempengaruhi aktivitas yang berkaitan dengan tugas dari para anggota kelompok.

Selanjutnya pengertian kepemimpinan lebih dipertajam lagi oleh Edwin A. Locke (1997), yakni sebagai berikut :

1. Kepemimpinan adalah suatu seni untuk menciptakan kesesuaian paham. Berarti setiap pemimpin melalui kerja sama yang sebaik-baiknya harus mampu membuat para bawahan mencapai hasil yang telah ditetapkan. Peranan pemimpin memberi dorongan terhadap bawahan untuk mengerjakan apa yang dikehendaki perusahaan. Dengan kata lain kepemimpinan adalah seni bagaimana membuat orang lain mengikuti serangkaian tindakan dalam mencapai tujuan.

2. Kepemimpinan adalah suatu bentuk persuasi dan inspirasi, maksudnya setiap pemimpin harus memiliki kemampuan mempengaruhi orang lain yang dilakukan bukan melalui paksaan, melainkan dengan cara himbauan dan persuasi.

3. Kepemimpinan adalah suatu kepribadian yang memiliki pengaruh. Dapat diartikan bahwa setiap pemimpin harus memiliki sifat dan watak yang menunjukkan keunggulan, sehingga pemimpin tersebut memiliki pengaruh terhadap bawahan.

4. Kepemimpinan adalah suatu tindakan dan perilaku. Maksudnya menggambarkan rangkaian perilaku seseorang yang mampu mengarahkan kegiatan secara bersama, mampu dalam menilai bawahan, mampu dalam mengikat kerja sama bawahan, serta mampu memperhatikan bawahan dan sebagainya.

5. Kepemimpinan adalah suatu titik sentral proses kegiatan kelompok. Dalam hal ini kepemimpinan melahirkan berbagai gagasan baru, yang memberikan dorongan lahirnya perubahan atau perbaikan kegiatan dan seluruh proses kegiatan kelompok, baik dari segi struktur, suasana dan aktivitas kelompok tersebut.

6. Kepemimpinan adalah suatu hubungan kekuatan dan kekuasaan. Dalam hal ini kepemimpinan adalah suatu bentuk hubungan sekelompok orang. hubungan antara yang memimpin dan yang dipimpin. Hubungan yang dimaksudkan harus mencerminkan perilaku kepemimpinan yang berwibawa. Dengan kata lain, pemimpin harus lebih banyak mempengaruhi daripada dipengaruhi.

7. Kepemimpinan adalah sarana pencapaian tujuan. Dalam hal ini pemimpin harus memiliki suatu program dan perilaku bersama-sama anggota kelompok dengan menggunakan cara atau gaya tertentu, sehingga kepemimpinan mempunyai peranan 
sebagai kekuatan dinamik, mendorong. memotivasi, mengkoordinasi dalam mencapai tujuan yang telah ditentukan.

8. Kepemimpinan adalah suatu hasil interaksi. Dengan kata lain, kepemimpinan adalah proses sosial yang merupakan hubungan antar pribadi, di mana pihak lain mengadakan penyesuaian, suatu proses saling mendorong dalam mencapai tujuan bersama. Dengan demikian kepemimpinan bukan merupakan sebab, tetapi akibat atau hasil dari kelompok itu sendiri. Jadi kepemimpinan adalah benar, jika diakui dan didukung oleh anggota kelompok.

9. Kepemimpinan adalah suatu peranan yang dibedakan. Definisi menggambarkan bahwa dalam kehidupan organisasi masing-masing anggota mempunyai peranan yang berbeda, kemampuan yang berbeda dalam mencapai suatu tujuan dan sebagainya. Kepemimpinan yang muncul sebagai akibat interaksi dalam kehidupan organisasi karena kelebihan kemampuan, maka diangkat peranannya sebagai pemimpin.

10.Kepemimpinan adalah suatu inisiatif struktur. Definisi ini menunjukkan bahwa kepemimpinan jangan dipandang sebagai jabatan pasif. Akan tetapi. harus berperan sebagai jabatan yang terlibat dalam suatu tindakan memenuhi pembentaan struktur dalam interaksi sebagai bagian dari proses pemecahan masalah bersama.

Dari berbagai pengertian di atas, sinambela dkk (2008) mencoba memberi kesimpulan bahwa secara umum pengertian kepemimpinan adalah suatu kewenangan yang disertai kemampuan seseorang dalam memberikan pelayanan untuk menggerakkan orang-orang yang berada di bawah koordinasinya dalam usaha mencapai tujuan yang ditetapkan suatu organisasi.

\section{b. Pengertian Budaya Organisasi}

Budaya adalah suatu pola asumsi dasar yang ditemukan dan dikembangkan oleh suatu kelompok tertentu karena mempelajari dan menguasai masalah adaptasi eksternal dan integrasi internal, yang telah bekerja dengan cukup baik untuk dipertimbangkan secara layak dan karena itu diajarkan pada anggota baru sebagai cara yang dipersepsikan, berpikir dan dirasakan dengan benar dalam hubungan dengan masalah tersebut (Edgar Schein, 1997).

Geert Hofstede menyatakan bahwa budaya terdiri dari mental program bersama yang mensyaratkan respons individual pada lingkungannya. Definisi tersebut mengandung makna bahwa kita melihat budaya dalam perilaku sehari-hari, tetapi dikontrol oleh mental program yang ditanamkan sangat dalam. Budaya bukan hanya perilaku di permukaan, tetapi sangat dalam ditanamkan dalam diri kita masing-masing (David C. Thomas dan Kerr Inkson, 2004).

Webster's New Collegiate Dictionary mendefinisikan budaya sebagai pola terintegrasi dari perilaku manusia termasuk pikiran, pembicaraan, tindakan, dan artifak serta tergantung pada kapasitas orang untuk menyimak, dan meneruskan pengetahuan kepada generasi penerus (Terrence E. Deal dan Allan A. Kennedy, 2000).

Dari pendapat para pakar tersebut di atas dapat disimpulkan bahwa budaya merupakan pola kegiatan manusia yang secara sistematis diturunkan dari generasi ke 
generasi melalui berbagai proses pembelajaran untuk menciptakan cara hidup tertentu yang paling cocok dengan lingkungannya.

Adapun penerapan budaya tersebut di dalam organisasi menjadi budaya organisasi. Di antara para pakar memberikan pengertian tentang budaya organisasi dengan cara sangat beragam, karena masing-masing memberikan tekanan pada sudut pandang masing-masing. Hal seperti itu adalah wajar, seperti kita memandang sebuah benda dari sudut yang berbeda, maka masing-masing akan mendeskripsikan apa yang terlihat dalam pandangannya.

Namun, di antara pendapat para pakar tersebut pada umumnya bersumber pada pandangan Edgar Schein yang mengemukakan bahwa budaya organisasi adalah sebagai filosofi yang mendasari kebijakan organisasi, aturan main untuk bergaul, dan perasaan atau iklim yang dibawa oleh persiapan fisik organisasi (Robert P. Vecchio, 1995).

Adapun Jerald Greenberg dan Robert A. Baron (2003) menyatakan budaya organisasi sebagai kerangka kerja kognitif yang terdiri dari sikap, nilai-nilai, norma perilaku dan harapan yang diterima bersama oleh anggota organisasi. Akar setiap budaya organisasi adalah serangkaian karakteristik inti yang dihargai secara kolektif oleh anggota organisasi.

Budaya organisasi menurut Stephen P. Robbins (2003) adalah sebuah persepsi umum yang dipegang oleh anggota organisasi, suatu sistem tentang keberartian bersama. Budaya organisasi berkepentingan dengan bagaimana pekerja merasa-Kan karakteristik suatu budaya organisasi, tidak dengan apakah seperti mereka atau tidak.

Adapun Michael Zwell (2000) menyatakan budaya korporasi sebagai cara hidup suatu organisasi yang diberikan melalui generasi penerus pekerja. Budaya termasuk siapa kita, apa yang kita yakini, apa yang kita lakukan, dan bagaimana melakukannya.

Dari pengertian tersebut diatas, dapat disimpulkan bahwa budaya organisasi adalah filosofi dasar organisasi yang memuat keyakinan, norma-norma, dan nilai-nilai bersama yang menjadi karakteristik inti tentang bagaimana cara melakukan sesuatu dalam organisasi. Keyakinan, norma-norma, dan nilai-nilai tersebut menjadi pegangan semua sumber daya manusia dalam organisasi dalam melaksanakan kinerjanya.

\section{PERAN PEMIMPIN DALAM MENCIPTAKAN BUDAYA ORGANISASI}

Dalam suatu organisasi, faktor kepemimpinan memegang peranan yang penting karena pemimpin itulah yang akan menggerakkan dan mengarahkan organisasi dalam mencapai tujuan dan sekaligus merupakan tugas yang tidak mudah. Tidak mudah, karena harus memahami setiap perilaku bawahan yang berbeda-beda. Bawahan dipengaruhi sedemikian rupa sehingga bisa memberikan pengabdian dan partisipasinya kepada organisasi secara efektif dan efisien. Dengan kata lain, dapat dikatakan bahwa sukses tidaknya usaha pencapaian tujuan organisasi, ditentukan oleh kualitas kepemimpinan (Sutrisno, 2009)

Organisasi tidak terbentuk dengan secara kebetulan dan secara spontan. Namun, organisasi berorientasi pada tujuan, mempunyai maksud spesifik, dan diciptakan karena satu atau dua orang merasa bahwa dengan tindakan yang terkoordinasi dan bersama- 
sama dari sejumlah orang dapat menyelesaikan sesuatu yang tidak dapat dilakukan dengan tindakan individual.

Pendiri biasanya mempunyai pengaruh utama pada bagaimana kelompok pada awalnya didefinisikan dan menyelesaikan masalah adaptasi eksternal dan integrasi internal. Karena mereka mempunyai gagasan awal, mereka akan mempunyai catatan sendiri berdasar pada sejarah budaya mereka dan kepribadian, tentang bagaimana memenuhi gagasan.

Pendiri tidak hanya mempunyai rasa percaya diri dan pertimbangan pada tingkat tinggi, tetapi mempunyai asumsi kuat tentang sifat dunia, peran yang dijalankan organisasi, sifat wajar manusia dan hubungan, bagaimana kepercayaan dicapai dan bagaimana mengelola waktu dan ruang.

Pemimpin pendiri cenderung mempunyai teori kuat tentang bagaimana melakukan sesuatu, teori mereka perlu diuji sebelumnya. Apabila asumsi mereka salah, kelompok akan gagal di awal sejarahnya. Apabila asumsinya benar, mereka menciptakan organisasi yang kuat di mana budaya mencerminkan asumsi awalnya.

Mereka menciptakan budaya dengan tindakan dan keputusan mereka baik secara sadar maupun tidak sadar. Adalah menakutkan dan mengecilkan hati bagi orang dalam posisi kepemimpinan untuk menyadari bagaimana perilaku mereka membantu menciptakan budaya mereka, tanpa memandang apakah mereka bermaksud melakukannya.

\section{KEPEMIMPINAN DAN BUDAYA ORGANISASI}

Setiap langkah kecil seorang pemimpin dalam budaya organisasi, seperti halnya dalam memimpin komponen bisnis lain, adalah penting bagi sukses organisasi. Kesalahan langkah dalam budaya organisasi dapat menyebabkan kegagalan. Apabila terdapat kekurangan kepemimpinan dalam budaya organisasi, maka organisasi secara keseluruhan kekurangan kapemimpinan.

Banyak faktor yang memengaruhi keberhasilan atau kegagalan suatu organisasi dalam mencapai tujuannya, dalam menyesuaikan diri dengan perkembangan Iingkungan, dan dalam upaya untuk mempertahankan kelangsungan hidupnya. Akan tetapi sebagian besar faktor tersebut dipengaruhi oleh pemimpin, balk sifat yang melekat pada pemimpin maupun gaya kepemimpinan yang digunakan dalam mengelola organisasi tersebut (Dongoran, 2004).

Gaya kepemimpinan merupakan norma perilaku yang digunakan oleh seorang pemimpin pada saat pemimpin tersebut mencoba untuk memengaruhi orang lain. Dalam teori kepemimpinan ada beberapa gaya kepemimpinan yang dapat digunakan. Kemampuan seorang pemimpin dalam memengaruhi pengikutnya merupakan faktor dominan yang menentukan keberhasilan suatu organisasi, karena pemimpin memiliki peran sebagai koordinator, motivator, dan katalis yang akan membawa organisasi pada puncak keberhasilan. Pemimpin memiliki peran yang sangat penting dalam menentukan arah dan tujuan organisasi. Oleh sebab itu keberhasilan atau kegagalan organisasi selalu diasosiasikan dengan pemimpinnya (Fachrunnisa, 2008). 
Namun sayangnya, menurut Jerome Want (2006: 148) pada umumnya hanya terdapat tiga kategori pemimpin organisasi, yaitu pemimpin yang selalu mengatakan: (1) I don't know (saya tidak tahu), (2) I don't know how (saya tidak tahu bagaimana), dan (3) I don't care (saya tidak peduli). Sedikit sekali yang benar-benar menyadari tentang bagaimana memimpin seluruh organisasi bisnis, dan hal tersebut memerlukan pemahaman masalah budaya yang kompleks.

Menurut Yukl (2007) kepemimpinan adalah proses memengaruhi orang lain untuk memahami dan setuju dengan apa yang harus mereka lakukan dan bagaimana melakukan tugas tersebut secara efektif, serta proses untuk memfasilitasi upaya individu dan kelompok mencapai tujuan bersamalshared goal. Definisi tersebut tidak hanya mencakup upaya untuk memengaruhi dan memfasilitasi pekerjaan suatu kelompok atau organisasi, tetapi juga untuk memastikan bahwa semuanya dipersiapkan untuk menghadapi tantangantantangan di masa yang akan datang.

Greenberg dan Baron (2003) membedakan pengertian pemimpin/leader dengan kepemimpinan. Pemimpin adalah individu dalam suatu kelompok atau organisasi yang memiliki pengaruh lebih pada orang lain, sedangkan kepemimpinan adalah proses di mana seorang pemimpin memengaruhi individu atau anggota kelompok untuk mencapai suatu tujuan. Untuk mencapai tujuan tersebut pemimpin dapat menggunakan berbagai cara atau gaya agar seseorang atau kelompok dengan sukarela bersedia untuk melakukan sesuatu. Kepemimpinan lebih mendasarkan pada pengaruh/infuence daripada menggunakan paksaan. Jadi kepemimpinan adalah proses di mana seseorang atau pemimpin memengaruhi pengikut dengan cara-cara yang tidak memaksa untuk mencapai suatu tujuan.

Terdapat perbedaan antara kepemimpinan dan manajemen masih menjadi kontroversi, seorang ahli kepemimpinan Bernard Bass dalam Wibowo (2011) menyimpulkan bahwa para pemimpin mengelola dan manajer memimpin, tetapi kedua aktivitas tersebut berbeda. Meskipun kepemimpinan dan manajemen saling tumpang tindih, masing-masing melibatkan serangkaian aktivitas/fungsi yang unik. Manajer biasanya melaksanakan fungsi-fungsi yang berkaitan dengan perencanaan, penyelidikan, pengorganisasian, dan pengawasan, sedangkan pemimpin berurusan dengan aspek-aspek antar pribadi dari pekerjaan seorang manajer.

Pemimpin juga memberikan inspirasi kepada bawahan, memberikan dukungan emosional, mencoba menggerakkan karyawan ke arah pencapaian tujuan, serta menciptakan suatu visi dan rencana strategis untuk suatu organisasi. Sedangkan manajer bertugas menerapkan visi dan rencana strategis.

Tugas manajer sekarang kebanyakan adalah: mengelola risiko, investasi pemegang saham, pengembangan produk baru, mergers, downsizing, menangani berbagai krisis, mengelola pendapat publik, dan mengatasi pekerja dengan kinerja rendah. Namun, hanya sedikit yang memahami bagaimana memimpin seluruh organisasi bisnis, yang memerlukan pemahaman masalah budaya yang sangat kompleks. Di abad perubahan radikal sekarang ini, organisasi bisnis memerlukan true leaders, bukan hanya manajer. Pemimpin bukan hanya terampil dalam menangani 
masalah teknis dalam berbisnis, namun dituntut ntuk memahami masalah budaya organisasi.

\section{BUDAYA DAN HARAPAN PENGIKUT}

Masalah budaya bukan hanya memfokus pada pemimpin, namun juga berkepentingan dengan para pengikutnya. Gagasan dari kepemimpinan adalah menemukan siapa yang ingin bertanggung jawab, atau siapa yang percaya bahwa posisi tradisional atau hierarki membuat mereka menjadi bertanggung jawab.

Namun, sebenarnya semua orang adalah bertanggung jawab, setiap orang mempunyai potensi untuk menjalankan kepemimpinan. Kepemimpinan merupakan terminologi pengaruh, dan memengaruhi mungkin dijalankan oleh setiap orang, dari mereka yang dalam posisi jabatan tertinggi sampai pada anggota terendah dalam organisasi.

Kepemimpinan adalah suatu proses dinamis. Hubungan pemimpin - pengikut adalah bersifat timbal balik dan berkembang melalui interaksi antar-pribadi dengan berjalannya waktu. Akan tetapi, penekanan dalam masyarakat kita adalah jelas pada atribut dan tindakan pemimpin (Sofyandi \& Iwa, 2007)

Dalam menghadapi perbedaan kelompok budaya, seorang pemimpin perlu memahami dimensi budaya yang dihadapi. Dimensi budaya dapat dilihat dari sifatnya (Wibowo, 2011), yaitu :

1. Individualistic atau colectivistic, masing-masing memerlukan gaya kepemimpinan yang berbeda. Dalam budaya individualistik, baik pemimpin maupun pengikut akan berusaha melibatkan diri dalam pengambilan keputusan untuk memaksimalkan pengaruh individual mereka dan mendapatkan hasil baik bagi mereka. Dalam budaya kolektivistik, orang melihat dirinya sebagai anggota kelompok dan kolektif, menyukai aktivitas kelompok, dan mengharapkan keputusan dilakukan berdasar konsensus atau konsultatif, di mana pengaruh keputusan pada setiap orang dipertimbangkan. Hal tersebut menunjukkan gaya kepemimpinan dari dua budaya yang berbeda.

2. Power distance, merupakan praktik kepemimpinan otokratik yang diadopsi dan ditoleransi budaya dengan high-power distance, di mana perbedaan kekuasaan yang besar antara atasan dan bawahan diharapkan dan ditoleransi. Sebaliknya apabila orang tidak dapat menerima perbedaan atau mengharapkan perlakuan yang sama, dinamakan low-power distance.

3. Uncertainty avoidance, dalam budaya dengan high uncertainty avoidance, pemimpin menstrukturkan pekerjaan bawahan, mungkin melalui birokrasi, dan membuat keputusan yang mungkin meningkatkan stabilitas, akan diharapkan berjalan baik. Adapun dalam budaya low uncertainty avoidance akan lebih banyak terdapat fleksibilitas dalam menjalankan pekerjaan.

4. Masculinity atau femininity, merupakan penekanan relatif pada yang secara tradisional menjadi ambisi tujuan dan prestasi pria dengan yang secara tradisional menjadi orientasi wanita untuk mengasuh dan harmoni interpersonal akan 
memengaruhi persepsi pemimpin. Pemimpin yang memelihara hubungannya dengan anggota kelompok sambil mengabaikan peluang pribadi untuk pengakuan dan promosi lebih umum terdapat dalam feminine culture, tetap: mungkin dipandang aneh dalam masculine culture.

Sejak lama telah dikenal adanya perbedaan antara kepemimpinan formal dan informal. Kepemimpinan formal, pemimpin secara formal ditunjuk dan mempunyai jabatan yang tepat. Kepemimpinan informal, di mana seseorang mempunyai status kepemimpinan karena respek atau penghormatan orang lain.

Pemimpin informal timbul karena gagasan atau perilaku mereka adalah merupakan representasi orang lain dan karena mereka mempraktikkan keterampilan memengaruhi yang baik dalam menempatkan gagasan tersebut kepada orang lain.

Secara ideal, pemimpin formal dan informal adalah prang yang sama, tetapi sering dalam situasi lintas budaya pemimpin formal dari budaya lain mungkin kurang diterima karena perbedaan budaya, terutama perbedaan dalam metode kepemimpinan yang diharapkan.

Mungkin terdapat pemimpin informal dari budaya setempat yang merepresentasikan gagasan orang kebanyakan dan menggunakan pengaruh untuk menyeimbangkannya. Hal ini dapat membuat penting bagi pemimpin formal, baik untuk menjalankan gaya kepemimpinan yang cocok dengan harapan lokal atau dapat bekerja dengan pemimpin informal (David C. Thomas dan Kerr Inkson, 2004).

\section{PERAN PEMIMPIN DALAM PERUBAHAN BUDAYA}

Budaya organisasi bisa kuat bisa juga lemah, tergantung pada berbagai faktor yang memengaruhi seperti kepaduan, consensus nilai, dan komitmen individu terhadap tujuan bersama. Budaya yang kuat bukan sesuatu yang baik, karena keberadaan nilai budaya sentral lebih penting daripada kekuatannya. Budaya yang kuat tetapi bertahan terhadap perubahan dapat menjadi sesuatu yang buruk dari sudut pandang kompetitif dan kemampuan mendapatkan keuntungan, dibandingkan budaya yang lemah tetapi inovatif (Kreitner dan Kinicki, 2005).

Kesamaaan visi, nilai-nilai dan keyakinan di antara anggota organisasi menunjukkan kuatnya budaya (strong culture). Sebaliknya, keragaman pandangan terhadap visi keyakinan dan nilai-nilai organisasi menunjukan lemahnya budaya (weak culture). Sathe (dalam Sobirin, 2007) misalnya mengatakan bahwa yang dirnaksud budaya yang kuat (strong culture) adalah "... is characterized by the organization's core values being intensely held, clearly ordered, and widely shared".

Dalam pandangan Sathe, budaya yang kuat ditandai oleh nilai-nilai inti organisasi yang tertanam semakin mendasar, kokoh dan dipegang teguh oleh para anggota organisasi. Semua itu bisa terjadi karena budaya tersebut disampaikan secara jelas, disosialisasikan dan diwariskan sehingga semakin luas dianut oleh banyak anggota organisasi. Demikian sebaliknya, jika budaya hanya dipahami oleh sekelompok kecil orang bisa dikatakan sebuah organisasi merupakan budaya yang lemah (weak culture). 
Budaya organisasi yang kuat menunjukkan bahwa nilai-nilai inti organisasi dipegang teguh dan dijunjung bersama. Semakin banyak anggota organisasi yang menerima nilai-nilai inti dan semakin besar komitmen mereka terhadap nilai-nilai tersebut, semakin kuat budaya organisasi. Budaya organisasi yang kuat akan berpengaruh terhadap perilaku para anggota organisasi karena kadar kebersamaan dan intensitas yang tinggi akan menciptakan suasana internal berupa kendali perilaku yang tinggi.

Budaya korporasi yang efektif menunjukkan seperangkat kualitas dan keyakinan yang secara jelas memberi manfaat pada budaya perusahaan dan keseluruhan kinerja bisnis. Hal tersebut dapat dilakukan semua orang dalam organisasi, tetapi Chief Executive Officer mempunyai kelebihan yang tidak dimiliki orang lain.

Chief Execcutive Officer dapat menetapkan agenda dan membuat sumber daya yang diperlukan tersedia dalam proses. Mereka juga menciptakan koalisi, menyingkirkan hambatan, dan yang paling penting memberi inspirasi orang. Chief Executive Officer mempunyai kekuatan untuk membuat perubahan budaya menjadi kenyataan, hanya jika mereka menggunakannya. Jerome Want (2006: 160) mengindikasi peranan seorang pemimpin untuk dapat melakukan perubahan budaya, yaitu :

1. Become a student of a culture (menjadi pelajar budaya)

Budaya perusahaan tidak dimiliki oleh seseorang dan pasti bukan oleh Chief Executive Officer. Budaya merupakan produk dari banyak kekuatan kontibutor selama bertahuntahun, pada dasarnya melalui perilaku orang, komitmen, dan praktik bisnis perusahaan, kebijakan, misi dan sejarah; dan kondisi industri.

Bila dalam pendirian belum secara sadar dibentuk, mungkin diperlukan waktu sepanjang hidupnya dan bahkan sulit untuk berubah. Setiap orang dalam budaya perlu menjadi pelajar budaya sebelum berusaha mengubahnya, termasuk Chief Executive Officer.

2. Renewal (pembaruan)

Chief Executive Officer secara unik diposisikan untuk membangun budaya sebagai proses pembaruan. Dengan memerbarui budaya perusahaan, bakat dan komitmen orang diberi energi ulang atas nama perusahaan.

Tidak ada downsizing, perbaikan operasi, business process reengineering atau restrukturisasi yang mempunyai pengaruh pembaruan terhadap perusahaan. Sebaliknya, ukuran ini hampir dapat dipastikan selalu meningkatkan stres pada budaya organisasi.

3. Communications (komunikasi)

Chief Executive Officer dan pemimpin perubahan harus memastikan terjadinya komunikasi secara terbuka dengan seluruh organisasi. Tidak ada yang dapat menciptakan ketidakpercayaan daripada menyelubungi proses perubahan budaya secara rahasia.

Ketika orang merasa ditinggalkan, kemarahan dan penolakan akan tumbuh. Komunikasi terbuka dengan tim perubahan juga penting sehingga orang di tempat yang sama dapat bertukar gagasan baru dan sumber daya. 


\section{Inclusiveness (keterlibatan)}

Chief Executive Officer harus membuat jelas pada organisasi bahwa membangun budaya merupakan proses pelibatan. suatu proses dengan menyertakan orangnya. Penyertaan orang tidak harus ditetapkan dengan mengeluarkan orang, tetapi harus dapat menjangkau seluruh tenaga kerja untuk gagasan dan komitmennya.

Manfaat utama dalam hal ini adalah akan tumbuh sepanjang waktu melibatkan setiap orang. Pemimpin baru diterima dalam proses untuk menunjukkan gagasan baru dan rekomendasi, dan juga gagasan menyimpang.

5. Trust (kepercayaan)

Chief Executive Officer harus menanamkan rasa percaya di antara peserta dalam proses membangun budaya. Orang harus merasa aman menyuarakan pendapatnya dan perbedaan tentang budaya yang baru diimpikan dan cara bagaimana proses dikelola.

Kepercayaan di antara anggota tim perubahan adalah penting apabila proses perubahan tidak diluncurkan. Apabila isu kepercayaan tumbuh, Chief Executive Officer akan menjadi orang terbaik untuk menyampaikan isu tersebut.

6. Accountability (akuntabilitas)

Tidak ada seorang pun dalam posisi lebih baik daripada menempatkan Chief Executive Officer sebagai orang yangbertanggung jawab. Hanya Chief Executive Officer yang dapat mempertimbangkan apakah proses perubahan budaya berjalan di arah yang benar dan menyelesaikan tujuan sebenarnya.

\section{KESIMPULAN}

Budaya organisasi tidak dapat dipisahkan dengan kepemimpinan dalam organisasi karena budaya organisasi tumbuh dan berkembang bersama pendiri dan pemimpin organisasi yang kuat. Perkembangan organisasi sangat tergantung pada kemampuan pemimpin. Namun, pemimpin dapat bertindak dengan benar dalam mengelola organisasi, tetapi juga tidak luput dari kemungkinan berbuat salah.

Pemimpin diharapkan juga mampu menangkap harapan dari para pengikutnya. Pada dasarnya para pengikut akan loyal pada pemimpin apabila harapannya terpenuhi. Oleh karena itu, pemimpin perlu mengakomodasi harapan pengikut sehingga mendapat dukungan penuh untuk mencapai tujuan organisasi yang dibebankan pada pemimpin.

Peranan pemimpin sangat menentukan terutama apabila diperlukan perubahan budaya organisasi, terlebih lagi dalam perkembangan global di mana terjadi interaksi antarbudaya. Karenanya pemimpin juga dituntut untuk menjadi pembelajar budaya organisasi, memiliki kemampuan mengelola budaya organisasi sesuai dengan tingkat pertumbuhan organisasi dan strategi yang dikembangkan dalam mencapai tujuan organisasi.

Para pemimpin harus dapat memastikan bahwa para karyawan menerima filosofi organisasi atau seperangkat nilai yang menekankan pelayanan pada unsur pokok organisasi, konsumen, pemegang saham, karyawan, dan peningkatan kepemimpinan. Sementara itu infrastruktur harus dapat mendorong secara konsisten dan mendukung 
filosofi atau nilai dasar organisasi dalam memuaskan kebutuhan unsur pokok organisasi dan peningkatan kepemimpinan (Kreitner dan Kinicki, 2005).

Kepemimpinan akan memperkuat budaya, dan dalam hal ini dengan cara yang tepat akan mampu meningkatkan motivasi kerja yang akan berujung pada peningkatan produktivitas dan kinerja karyawan maupun organisasi (Jusmaliani, 2011).

\section{DAFTAR PUSTAKA}

Deal, Terencce, E and Allan A Kennedy, Corporate Cultures, Perseus Publishing, Massachusetts, 2000

Dongoran, Johnson, Siklus Hidup Organisasi dan Gaya Kepemimpinan, Jurnal Ekonomi Bisnis dan Ekonomi, Vol X No 1, Maret, 2004

Fachrunnisa, Olivia, Perbedaan Gender dalam Penggunaan Gaya Kepemimpinan Tranfomasional : Suatu Pengujian Dari Perspektif Atasan, Bawahan, Rekan Kerja dan Diri Sendiri, Jurnal Akutansi \& Manajemen, Vol 19, April 2008

Greenberg, Jerald and Robert A. Baron, Behavior in Organizations, Prentice Hall Inc, New Jersey, 2003

Jusmaliani, Pengelolaan Sumber Daya Insani, Bumi Aksara, Jakarta, 2011

Kreitner, Robert, and Angelo Kinicki, Organizational Behavior, McGraw Hill Higher Education, New York, 2001

Locke, Edwin A, Esensi Kepemimpinan, Mitra Utama, Jakarta, 1997

Moeljono, Djokosantoso, Cultured : Budaya Organisasi Dalam Tantangan, Elex Media Komputindo, Jakarta, 2005

Robbins, Stephen P, Organizational Behavior, Prentice Hall Inc, New Jersey, 2003

Rost, Joseph C, Kepemimpinan, terjemahan Triantoro Safaria, Graha Ilmu, Jakarta, 2004

Schein, Edgar H, Organizational Culture and Leadership, Jossey-Bass, San Fransisco, 1997

Sinambela, Lijan Poltak, dkk, Reformasi Pelayanan Publik : Teori, Kebijakan dan Implementasi, Bumi Aksara, Jakarta, 2008

Sobirin, Ahmad, Budaya Organisasi : Pengertian, Makna dan Aplikasinya Dalam Kehidupan Organisasi, STIM YPKN, Yokjakarta, 2007

Sofyandi, Herman \& Iwa Garniwa, Perilaku Organisasi, Graha Ilmu, Jakarta, 2007

Sopiah, Perilaku Organisasional, Penerbit Andi, Yokjakarta, 2008

Sunyoto, Danang \& Burhanuddin, Perilaku Organisasional, Penerbit CAPS, Yokjakarta, 2011

Sutrisno, Edi, Manajemen Sumber Daya Manusia, Kencana Prenada Media Grup, Jakarta, 2009

Thomas, David C, and Kerr Inkson, Cultural Intellegence, Barrett-Koehler Publisher Inc, San Fransisco, 2004

Vecchio, Robert P, Organizational Behavior, Harcourt Brace \& Company, Orlando, 1995

Want, Jerome, Corporate Culture, St Martin Press, New York, 2007

Wibowo, Budaya Organisasi : Sebuah Kebutuhan Untuk Meningkatkan Kinerja Jangka Panjang, RajaGrafindo Persada, Jakarta, 2011

Zwell, Michael, Creating a Culture of Competence, Jhon Willey and Sons, New York, 2000 